tion than that resulting from the continuous system. Further, all $\gamma$-globulin bands obtained by the discontinuous system were located closer to the albumin zone as noted previously ${ }^{13}$. Nevertheless, certain pathological $\gamma$-globulins $(1 b, c, d)$ still migrated towards the cathode.

Paper electrophoresis at $p \mathrm{H} 8.6$ in citrate barbitur. ate buffer of the sera investigated demonstrated in each case a significant increase of the proteins which migrated with mobilities corresponding to those of the $\gamma$-globulins. The increase over the normal value was 23-34 relative per cent. As judged by ultracentrifugal analysis the 7S-globulins of the same sera varied between 30 and 40 per cent. The 19S-component appeared approximately normal in concentra tion. Abnormal plasma proteins with sedimentation coefficients of 10 and $14 \mathrm{~S}$, respectively, were observed. in one case (1e) only.

The present starch-gel electrophoretic investigation on pathological $\gamma$-globulins demonstrates that this procedure offers an advantage over paper electrophoresis in that certain abnormal $\gamma$-globulins can be resolved into several bands. This resolution seems to indicate that these pathological $\gamma$-globulins display a discontinuous spectrum with respect to apparent mobility in contrast to the continuous spectrum of the normal $\gamma$-globulins. If the mobility of the 7S- $\gamma$-globulins may be related to the net charge of these molecules, then this observation can be interpreted to mean that certain pathological $\gamma$-globulins are synthesized in such a way that they carry relatively unlike electrostatic net charges.

This work was supported by grants from the Lilly Research Laboratories, Eli Lilly and Co., and from the National Institutes of Health $[A-3456(C 1)]$, United States Public Health Service.

Note added in proof. After this communication had been submitted, an article by Owen, Got and Silberman (Clin. Chim. Acta, 3, 605; 1958) came to our attention, in which the heterogeneity of the $\gamma$-globulins of patients with myeloma is described.

${ }^{1}$ Porter, R. R., in The Plasma Proteins, edit. by Putnam, F. W. (Acad. Press, New York, 1960).

${ }^{3}$ Gitlin, D., Gross, P. A. M., and Janeway, C. A., Nero England $J$. Med., $260,21,72(1959)$.

'Isliker, H. C., Adv. Protein Chem., 12, 388 (1957).

${ }^{4}$ Heremans, J., Les Globulines Sériques du Systeme Gamma (Masson, Paris, 1960).

- Cann, J. R., Brown, R. A., and Kirkwood, J. G., J. Biol. Chem. 181, 161 (1949).

'Fahey, J. L., and Horbett, A. P., J. Biol. Chem., 234, 2645 (1959).

; Dray, S., Science, 182, 1313 (1960).

${ }^{8}$ Smithies, O., Adv. Protein Chem., 14, 65 (1959).

- Poulik, M. D., Nature, 180, 1477 (1957).

${ }^{10}$ Poulik, M. D., and Smithies, O., Biochem. J., 68, 636 (1958).

"Marnay, A., Moretti, J., and Jayle, M. F., Rev. Franc. et Clin. Biol,, 4, $366(1959)$.

${ }^{13}$ Biserte, G., Havez, R., and Laturaze, J., C.R. Soc. Biol., 154, 132 $(1960)$. ${ }^{13}$ Poulik, M. D., Zuelzer, W. W., and Meyer, R., Nature, 184, 1800

\title{
GAMMA-GLOBULIN AND ACQUIRED IMMUNITY TO HUMAN MALARIA
}

\author{
BY Dr. S. COHEN \\ Department of Immunology, St. Mary's Hospital Medical School, London, W.2 \\ AND \\ DR. I. A. MCGREGOR and S. CARRINGTON \\ Medical Research Council Laboratories, The Gambia, West Africa
}

$\mathrm{M}$ ALARIAL infection is followed by the development of immunity which is specific for the homologous parasite, but ineffective against heterologous strains and species ${ }^{1-4}$. The epidemiological effects of acquired immunity in man are seen among the inhabitants of hyperendemic malarious regions who show a consistent pattern of susceptibility to infection. Infants born in such regions are relatively resistant during the first three months of life and thereafter all children suffer severe and recurrent attacks of the disease. Clinical malaria becomes comparatively infrequent in later childhood and among adults is rarely seen in acute form ${ }^{5,6}$.

The response of phagocytic cells in malarial infection was shown in early histological work ${ }^{2}$, and for many years resistance to the disease was considered to be exclusively cellular in nature. In 1937, Coggeshall and $\mathrm{Kumm}^{8}$ demonstrated the passive transfer of malarial immunity in rhesus monkeys and so established the presence of protective antibodies. However, the therapeutic effect of large doses of immune serum was evident only against minimal numbers of parasites and has not been demonstrated convincingly in man. The belief is therefore still prevalent that circulating antibodies play a relatively unimportant part in acquired malarial immunity ${ }^{9}$.

\section{Passive Transfer of Human Malarial Immunity}

In this investigation the role of eirculating antibody in malarial immunity has been studied in subjects living in The Gambia which is a hyperendemic area of West Africa. The therapeutic effect of $\gamma$-globulin prepared from the serum of apparently immune adults has been tested in young African children suffering from severe clinical malaria with dense parasitæmia. The $\gamma$-globulin prepared by chromato. graphy on columns of diethylaminoethyl cellulose ${ }^{10}$ was homogeneous on electrophoresis and in the ultracentrifuge appeared as a main peak with a sedimentation coefficient $\left(S^{6}{ }_{20}, W\right)=6.78$; an additional heavier component $(10 S)$ comprised less than 5 per cent of the total protein. The remainder of the protein eluted from the columns (referred to here as $\gamma$-free serum) was shown by serological tests to contain about $70 \mathrm{mgm}$. 7S $\gamma$-globulin and $20 \mathrm{mgm}$. 19S $\gamma$-globulin/gm. total protein.

Twelve children aged 4 months $-2 \frac{1}{2}$ years (weight $5 \cdot 4-12 \cdot 6 \mathrm{kgm}$.) admitted with a clinical diagnosis of malignant tertian malaria and an initial parasitæmia of $10,000-230,000 / \mathrm{c} . \mathrm{mm}$. received $\gamma$-globulin by intramuscular injection at intervals of 8-24 hr. for 3 days. The total dose was $1 \cdot 2-2 \cdot 5 \mathrm{gm}$./child which 


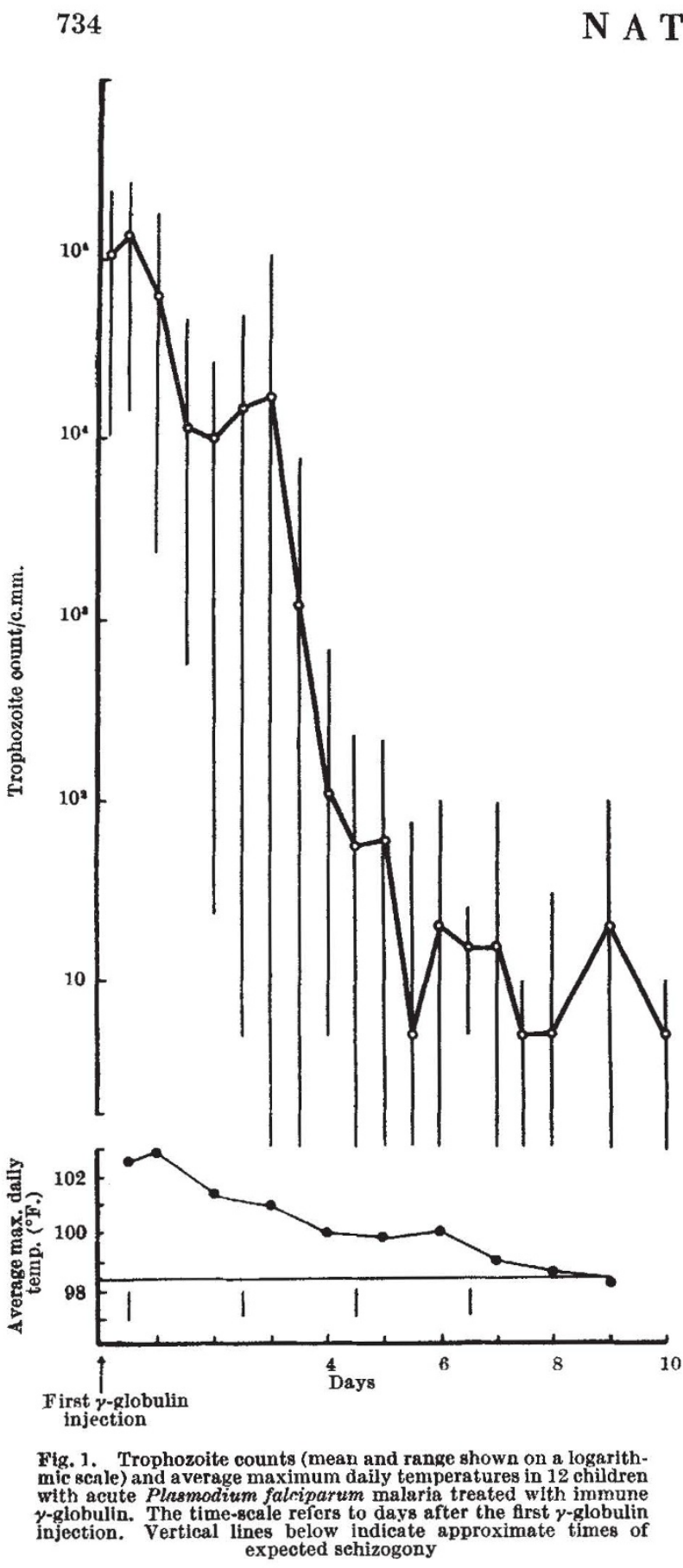

was equivalent to $10-20$ per cent of the recipient's own $\gamma$-globulin.

The infections were predominantly synchronous and $\gamma$-globulin therapy was usually started when the peripheral blood contained a high density of young ring forms. Blood examinations were made at 12hourly intervals and the course of parasitæmia is shown in Fig. 1. By the fourth day after the inception of treatment parasite counts were always less than 1 per cent of the initial values; by the ninth day trophozoites were not detectable in 8 out of 12 cases and the maximum count was $80 /$ c.mm. (Fig. 1). The fall in parasitæmia was accompanied by progressive alleviation of clinical illness although temperatures did not usually return to normal before the seventh

day (Fig. 1). No alterations in parasite morphology have been observed during treatment; however, in malignant tertian infections only immature parasites are detectable in peripheral blood. The immune $\gamma$-globulin appears to be effective both against Plasmodium falciparum and $P$. malariae (Fig. 2), but probably has no action against gametocytes (Fig. 3).

Two children aged 2-3 years failed to respond to the injection of $1.2 \mathrm{gm}$. $\gamma$-globulin. They had been admitted with pneumonia and measles respectively,

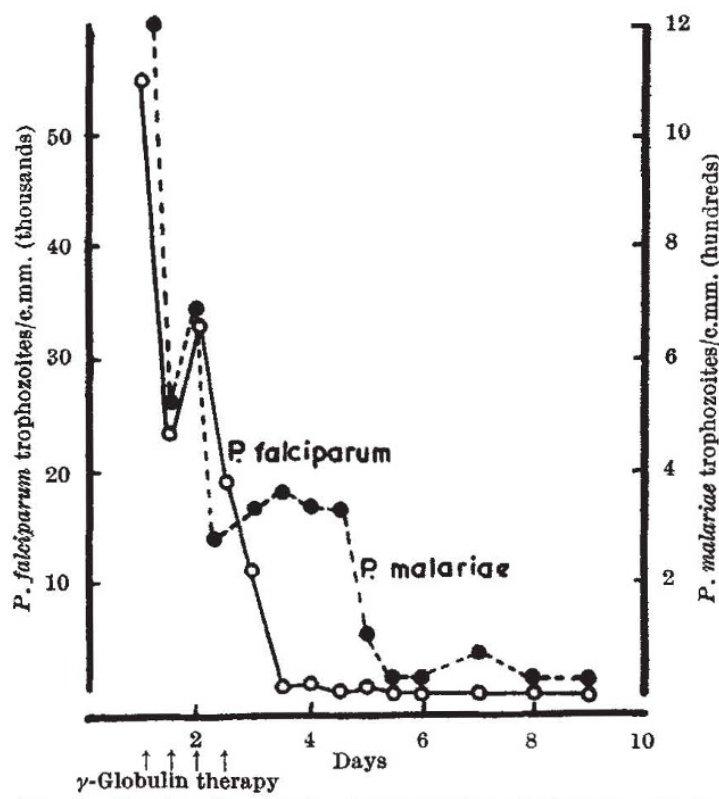

Fig. 2. Trophozoite counts of Plasmodium falciparum and $P$. malariae in ahld with a mixed infection treated with immune $\boldsymbol{\gamma}$-globulin; arrows show times of administration of $\gamma$-globulin by

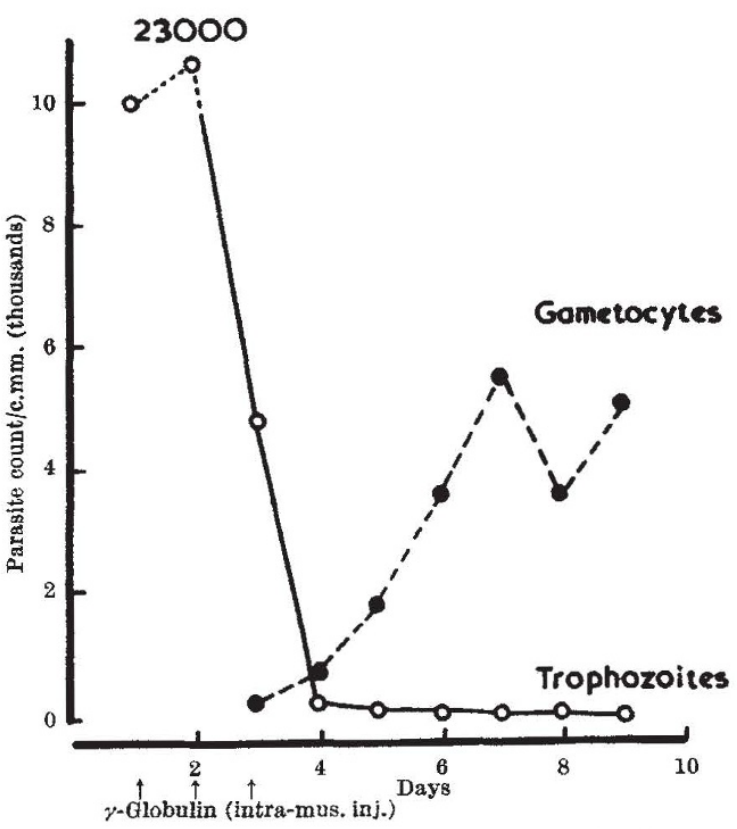

Fig. 3, Trophozoite and gametocyte counts in a chlld with acut Plasmodium falciparum malaria treated with immune $\gamma$-globulin. Arrows show time of administration of $\gamma$-globulin by intramuscular injection 


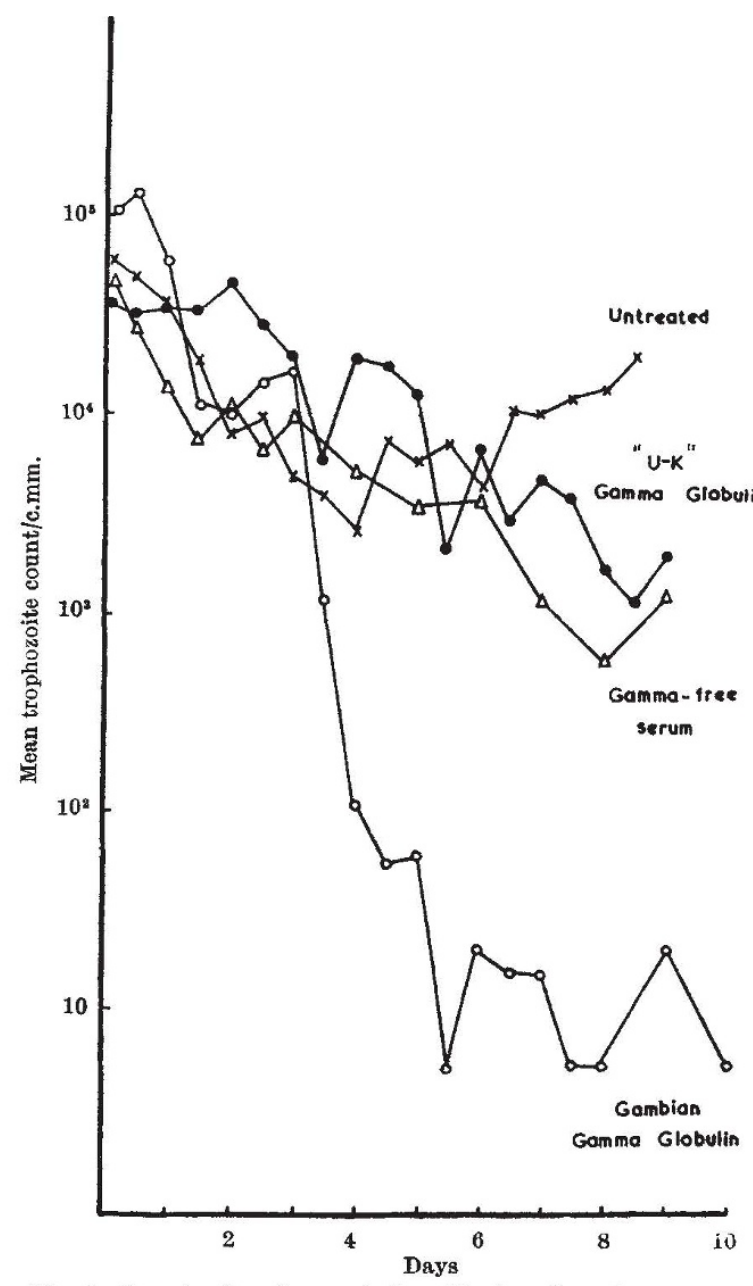

Fig. 4. Mean trophozoite counts (logarithmic scale) in four groups of children with acute Plasinoditum falciparum malaria. The treated children received either (i) $\gamma$-globulin prepared from blood donors in Great Britain, or (ii) serum prepared from Gambian adults and containing 7 per cent $7 \mathrm{~S} \gamma$-globulin and 2 per cent $19 \mathrm{~S}$

and in both $P$. falciparum parasitæmia of relatively low density $(8,000$ and $16,000 /$ c.mm. $)$ was an incidental finding. Failure in these cases was probably due to inadequate dosage since 3 children of
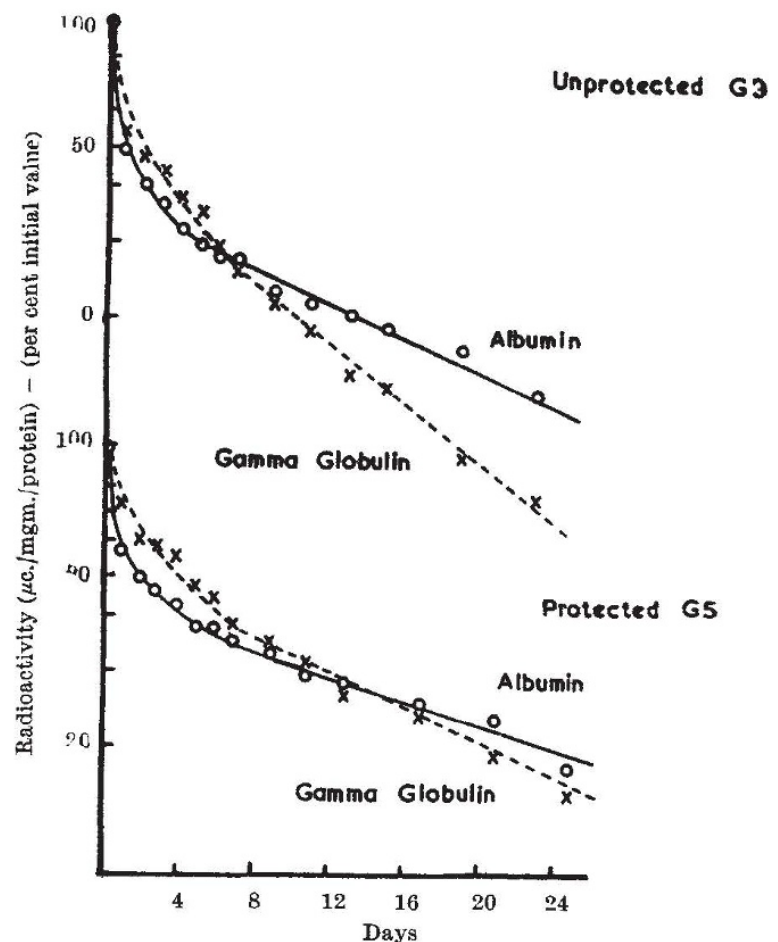

Fig. 5. Plasma elimination of ${ }^{181} \mathrm{I}$-albumin and ${ }^{125} \mathrm{I}-\gamma$-globulin in an unprotected adult Gambian and in a similar subject who in received 'Pyrimethamine' (25 mgm./week) for 6 years

comparable weight (10-12 kgm.) responded to the injection of 1.8-2.5 gm. $\gamma$-globulin.

In further experiments, 7 children with acute $P$. falciparum malaria received the $\gamma$-free fraction of Gambian serum (0.8-1.4 gm.). A single batch was used in all experiments and no child has developed signs of serum hepatitis. In addition, 4 children received $\gamma$-globulin prepared from the sera of blood donors in Great Britain (Lister Institute, Elstree, Herts.) and 2 were kept under observation without anti-malarial therapy. Trophozoite counts usually decreased in all these children. However, the response was irregular, and between the fourth and tenth days the mean trophozoite counts were considerably greater than those observed after treatment with adult African $\gamma$-globulin (Fig. 4).

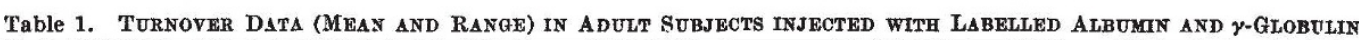

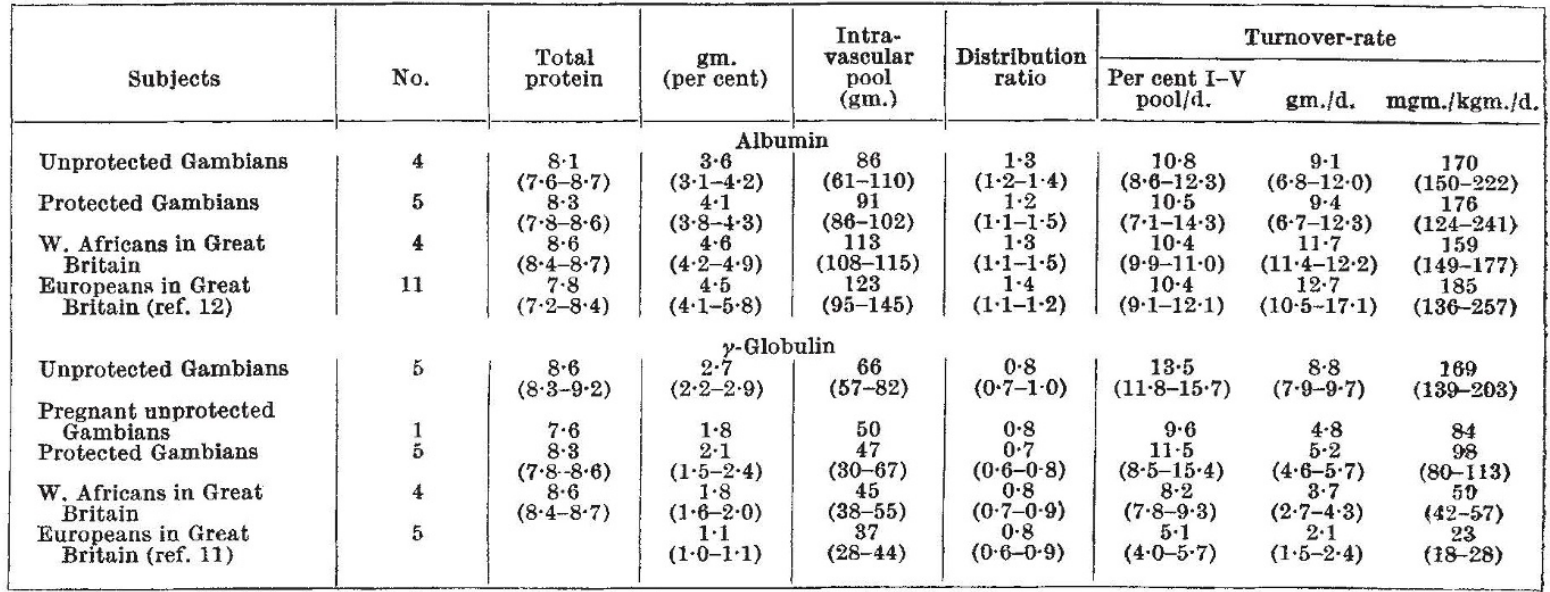

Distribution ratio = ratio extra- to intra-vascular protein mass 


\section{ALBUMIN SYNTHESIS}

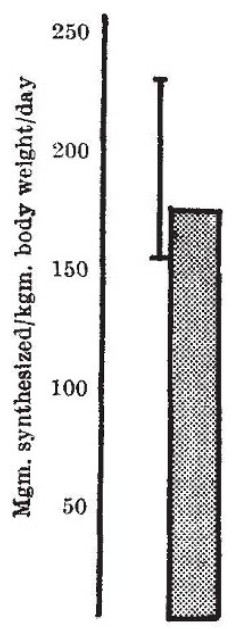

cannot be attributed to the selective catabolism of isotopically labelled malarial antibody since $\gamma$-globulins prepared from European and adult Gambian donors have identical elimination-rates (Fig. 7). Considerably less $\gamma$-globulin was synthesized by an unprotected subject who was three months pregnant at the time of study (Table 1); this finding is of interest in relation to the increased susceptibility to malarial infection described in pregnant women living in hyperendemic areas ${ }^{14,15}$.

West Africans resident for some years in the United Kingdom synthesized less $\gamma$-globulin than Gambian subjects maintained on anti-malarial therapy (Fig. 6); this difference must be attributed to environmental factors other than malarial infection. After several years in Great Britain, West Africans continue to synthesize $\gamma$-globulin at almost twice the rate observed in healthy Europeans; this may be due to environmental influences of early life or to genetically determined differences in $\gamma$-globulin metabolism.

\section{Mechanism of Acquired Malarial Immunity}

The preparation of $\gamma$-globulin from pooled sera of apparently hyperimmune donors and the use of susceptible children as recipients likely to have been exposed to homologous parasite strains, have provided optimum conditions for demonstrating the potency of naturally occurring malarial antibodies active against Plasmodium falciparum and probably also against $P$. malariae. The results show that the mechanism of acquired malarial immunity is basically similar to that observed with many other infections. being primarily dependent on the presence of protective antibodies which are associated with 7S $\gamma$-globulin. The response to immune $\gamma$-globulin.

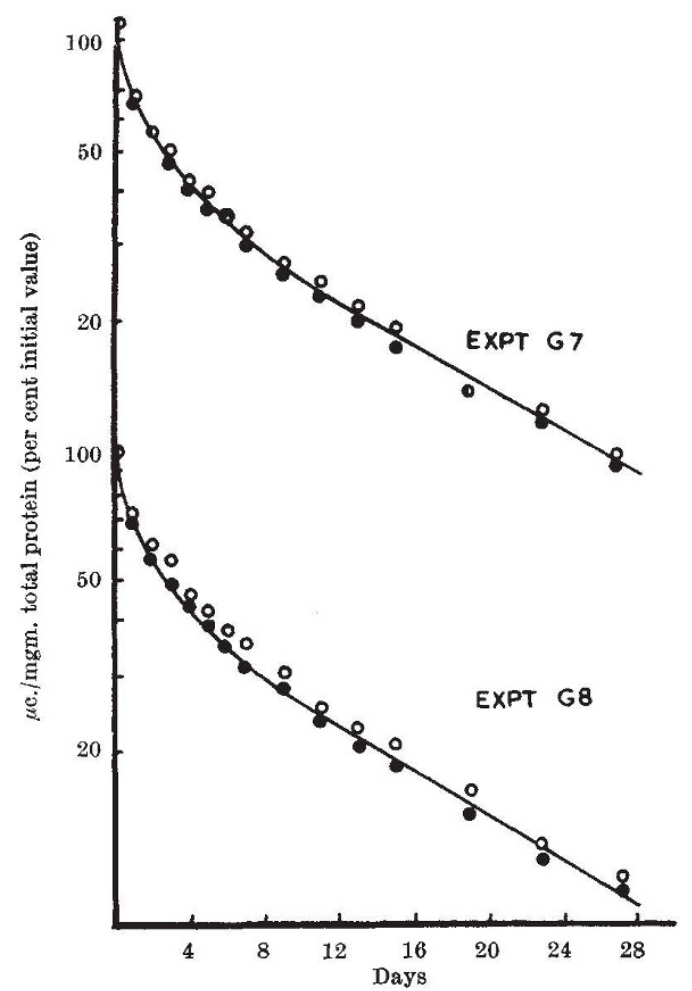

Fig. 7. Comparison in two unprotected African adults of the plasma elimination of $\gamma$-globulin prepared from European and Gambian donors and labelled with iodine-125 and lodine-131 respectively. , European $\gamma$-globulin; O, Gambian $\gamma$-globulin 
eonsidered in relationship to the cycle of parasite development as well as the absence of morphological changes in the parasites of peripheral blood, suggest that antibody acts either on mature intracellular forms or on merozoites liberated from red blood cells. Protection is of limited duration and a treated subject was again susceptible three months after receiving $\gamma$-globulin. Other fractions of immune serum including $19 \mathrm{~S} \gamma$-globulin did not appear to have a protective effect nor did the $\gamma$-globulin of European blood donors.

These findings support the hypothesis that the relative resistance of infants born in hyperendemic areas is due to passive transfer of protective antibodies from the mother. This process may, however, be rendered relatively ineffective by partial loss of malarial immunity during pregnancy ${ }^{14,15}$, which appears to be associated with a reduction in the rate of $\gamma$-globulin synthesis. Other factors, such as selective vector biting ${ }^{16}$, deficiency of $p$-aminobenzoic acid in milk-fed infants ${ }^{17,18}$ and the presence of a high proportion of fœtal hæmoglobin in circulating red cells ${ }^{1 \theta}$ may contribute to the suppression of malarial infection during early life.

In areas of hyperendemic malaria, immunity is established only after long exposure to intense infec. tion. This slow response is probably attributable both to the inherently poor antigenicity of the parasite and to the serological diversity of naturally occurring plasmodia. Acquired immunity is associated with hypergammaglobulinæmia 20,21 and with a striking increase in the rate of $\gamma$-globulin synthesis. Protection of Gambian adults against malaria over a period of several years reduced the average daily synthesis of $\gamma$-globulin by $3.5 \mathrm{gm}$., which is more than the total daily production in healthy Europeans. Since plasmodial infection leads to the produetion of complement-fixing antibodies ${ }^{22}$ and precipitins ${ }^{23}$, neither of which is species specific, it is likely that a considerable part of the $\gamma$-globulin synthesized in response to malaria is not protective antibody.

We wish to thank Sir Charles Harington, whose interest led to the initiation of this work, and Prof. R. R. Porter for much helpful discussion. We are grateful to Dr. D. Harling for clinical supervision of patients, Dr. W. d'A. Maycock for supplies of U.K. $\gamma$-globulin and Miss Margaret Polley for serological estimations of $19 S \gamma$-globulin. One of us (S. C.) is in receipt of a Medical Research Council grant.

\footnotetext{
${ }^{1}$ Coggeshall, I. T., Medicine, 22, 87 (1943).

Taliaferro, W. H., Immunity to the Malarial Infections (Malariology) edit. by M. F. Boyd, 935 (W. B. Saunders Co., Philadelphia and London).

${ }^{3}$ Ciuč̃, M., Chelărescu, M., Sofletea, A., Constantinescu, P., Teriteanu, E., Cortez, P., Balanovschi, G., and Kies, M., Bul. sti.

4 Sergent, E., Arch. Inst. Pasteur d'Algerie, 37, 1 (1959).

Wilson, D. B., Garnham, P. C. C., and Swellengrebel, N. H., Trop. Dis. Bull., 47, 677 (1950).

'McGregor, I. A., W. African Med. J., 6, 260 (1960).

' Golgi, C., Zentrabl. Bakt., 54 (orig.), 236 (1886).

${ }^{8}$ Coggeshall, L. T., and Kumm, H. W., J. Exp. Med., 66, 177 (1937).

${ }^{2}$ Sergent, E., and Sergent, E., Ind. J. Malariology, 10, 53 (1956).

${ }^{10}$ Sober, H. A., and Peterson, E. A., Fed. Proc, 17, 1116 (1958).

${ }^{11}$ Cohen, S., and Freeman, T., Biochem. J., 76, 475 (1960).

${ }^{12}$ Cohen, S., Freeman, T., and McFarlane, A. S., Clin. Sci., 20, 161 (1061).

${ }^{13}$ Matthews, C. M. E., Phys. Med. Biol., 2, 36 (1957).

${ }_{14}^{14}$ Bruce-Chwatt, I. J., Ann. Trop. Med. Parasit., 46, 173 (1952). ${ }^{15}$ MeGregor, I. A., and Smith, D. A., Trans, Roy. Soc. Trop. Med. Hyg.,
46, 403 (1952).

${ }^{18}$ Muirhead-Thompson, R. C., Brit. Med. J., i, 1114 (1951).

"Maegraith, B. G., Deegan, T., and Sherwood Jones, E., Brit. Med. J. ii, $1382(1952)$.

${ }^{28}$ Hawking, F., Brit. Med. J., 1, 1201 (1953)

${ }^{10}$ Allison, A. C., Brit. Med. J., i, 290 (1954).

${ }^{20}$ Gilles, H. M., and McGregor, I. A., Ann. Trop. Med. Parasit., 58 492 (1959).

${ }^{21}$ McGregor, I. A., and Gilles, H. M., Ann. Trop. Med. Parasit., 54 $275(1960)$.

${ }^{22}$ Eaton, M. D., and Coggeshall, L. T., J. Exp. Med., 70, 141 (1939).

${ }^{23}$ Pewny, W., Wien. klin. Wochschr., 31, 205 (1918).
}

\title{
MOISTURE EXPANSION RELATIONSHIPS FOR A FIRED KAOLINITE-HYDROUS MICA-QUARTZ CLAY
}

\author{
By DR. W. F. COLE \\ Commonwealth Scientific and Industrial Research Organization, Division of Building Research, Victoria, Australia
}

T carrying out a detailed study of the moisture expansion characteristics of a clay containing 30 per cent kaolinite (poorly organized), 30 per cent hydrous mica (poorly organized) of the following approximate composition :

$$
\begin{aligned}
& {\left[\mathrm{Si}_{6 \cdot 81} \mathrm{Al}_{1 \cdot 20}\right] \quad\left[\mathrm{Al}_{2 \cdot 42} \mathrm{Fe}_{1 \cdot 16} \mathrm{Mg}_{0 \cdot 04}\right]} \\
& {\left[\mathrm{Ca}_{0 \cdot 30} \mathrm{~K}_{0 \cdot 25} \mathrm{Na}_{0 \cdot 15} \mathrm{H}_{3} \mathrm{O}_{1 \cdot 42}\right] \quad \mathrm{O}_{20}(\mathrm{OH})_{4}}
\end{aligned}
$$

35 per cent quartz, 2 per cent hæmatite, and 1 per cent anatase, I have established relationships that might be found useful in interpreting the results from other clays and clay products.

The curves of moisture expansion versus firing temperature for specimens exposed to air for 90 days, and for specimens autoclaved at $220 \mathrm{lb} . / \mathrm{sq}$. in. for 2, 8, 30 and $200 \mathrm{hr}$. (measurements beginning from the same datum; specimens removed from the muffe at $300^{\circ} \mathrm{C}$. and cooled for $2 \mathrm{hr}$, in a dry desiccator before initial measurement) show that the autoclave expansion curves parallel the natural expansion curve and that at a firing temperature of about $1,000^{\circ} \mathrm{C}$. all have a maximum in expansion. If, however, autoclave expansion is plotted directly against natural expansion (Fig. 1), non-linear relationships exist over the firing range $950-1,200^{\circ} \mathrm{C}$. for all periods of autoclaving, and the points below and above $1,000^{\circ} \mathrm{C}$. separate into two curves for 30 and $200 \mathrm{hr}$. of autoclaving. (Linear relationships exist if autoclave expansion is plotted against the log of natural expansion.) Tho non-linear relationship expresses the fact that for this clay the ratio of autoclave expansion to natural expansion varies widely with firing temperature, and implies that there must be several reactive components produced over the range of firing temperature covered by the specimens. Mineralogical analysis has established that these reactive components are amorphous matter, glass, and anhydrous clay minerals. Amorphous matter, which is responsible for the coincident moisture expansion peak at about $1,000^{\circ} \mathrm{C}$. in autoclaved and naturally exposed specimens, is equally reactive to water vapour in the air or to steam under pressure, 